\title{
Electron microscope studies of the in vitro phagocytosis of Mycobacterium spp. by rainbow trout Oncorhynchus mykiss head kidney macrophages
}

\author{
Shih-Chu Chen ${ }^{1}$, Alexandra Adams ${ }^{2}$, Kim D. Thompson ${ }^{1, *}$, Randolph H. Richards $^{2}$ \\ 'Department of Veterinary Medicine, National Pingtung University of Science and Technology, Neipu, Pingtung 91207, Taiwan \\ ${ }^{2}$ Institute of Aquaculture, University of Stirling, Stirling FK9 4LA, Scotland, UK
}

\begin{abstract}
The cytological response of rainbow trout Oncorhynchus mykiss head kidney macrophages to ingested Mycobacterium spp. was examined in vitro. Mycobacterium marinum or Mycobacterium sp. TB267 isolated from snakehead fish Channa striata Bloch were opsonised with either fresh rainbow trout serum, serum which had been heat-inactivated, or rambow trout antiserum against the extracellular products (ECP) of the 2 Mycobacterium spp. A monoclonal antibody against the ECP was also used as an opsonin. Suspensions of macrophages were prepared ( $1 \mathrm{ml} \mathrm{of} 1 \times 10^{7}$ cells $\left.\mathrm{ml}^{-1}\right)$, mixed with the opsonised bacteria $\left(100 \mu \mathrm{l}\right.$ of $\left.2 \times 10^{9} \mathrm{ml}^{-1}\right)$, and incubated at $18^{\circ} \mathrm{C}$ for $0.5,1,2,4$ or $6 \mathrm{~h}$ to allow phagocytosis to occur. A quantitative evaluation of the phagocytosis of the mycobacteria by the macrophages was carried out by electron microscopy. Macrophage phagosomes and their contents were examined and numbers of intact and partially degraded bacteria determined. Pre-labelling dense granules (secondary lysosomes) with ferritin enabled phagosome lysosome fusion to be identified and their frequency determined. Opsonisation of the mycobacteria was found to greatly enhance the phagocytic and killing activity of the rainbow trout macrophages.
\end{abstract}

KEY WORDS: Macrophages $\cdot$ Phagocytosis $\cdot$ Phagosome Phagolysosome Mycobacterium sp

\section{INTRODUCTION}

Mycobacteriosis is a chronic bacterial disease of freshwater and marine fish (Nigrelli \& Vogel 1963) caused by acid-fast Mycobacterium spp. Mycobacterial infections induce systemic granulomas, especially in kidney and spleen of infected fish (Noga et al. 1989, 1990, Chinabut et al. 1990). The phagocytic and bactericidal activity of the macrophage, a component of the host defence mechanisms against pathogenic microorganisms, has been extensively studied in mammals (Krahenbuhl 1994, Rook \& Bloom 1994). Coating the pathogen with specific antibody, or opsonisation, makes the pathogen more susceptible to phagocytosis (Griffin 1983, Sakai 1984, Li \& Woo 1995). However,

\footnotetext{
-Addressee for correspondence. E-mail: kdt1@stir.ac.uk
}

little information is available on the effect of immunisation on phagocytosis or the intracellular killing of bacteria by fish macrophages, or the role that antibody or complement play in the opsonisation of bacteria.

The head kidney is one of the major organs involved in fish immune defence, and it is a tissue particularly rich in macrophages (Secombes 1990). Phagocytosis of most organisms is normally followed by a rapid fusion of lysosomes and phagosomes within the macrophage to form phagolysosomes. In view of this, macrophages from the head kidney of rainbow trout Oncorhynchus mykiss were used in this paper as a model to study the pathogenesis of mycobacteria at a cellular level. No literature is currently available to describe the interaction between Mycobacterium sp. and fish macrophages. Pre-labelling dense granules or secondary lysosomes with ferritin allowed identification, occurrence and frequency of phagosome lysosome fusion to 
be investigated (Armstrong \& Hart 1971). The objectives of the study were to investigate the ability of macrophages to phagocytosis mycobacteria exposed to a variety of opsonins in vitro and determine their influence on the rate of phagocytosis, and to examine phagosome-lysosome fusion within fish macrophages by pre-labelling lysosomes with ferritin. Phagocytosis of mycobacteria by macrophages of fish infected with mycobacteriosis was then examined in vivo.

\section{MATERIALS AND METHODS}

Bacteria. Mycobacterium sp. (TB267) isolated from snakehead fish Channa striata (Bloch) infected with mycobacteriosis in Thailand and a reference strain of $M$. marinum isolated from neon tetra Paracheirodon innesi (Myers) (1298) obtained from the National Collection of Industrial and Marine Bacteria, Aberdeen, UK, were compared in the following study. Bacteria were cultured in modified Sauton's medium for $10 \mathrm{~d}$ at $28^{\circ} \mathrm{C}$ and harvested by centrifugation at $6000 \times g$ for $30 \mathrm{~min}$. Bacteria were washed with phosphate buffered saline (PBS: $0.02 \mathrm{M} \mathrm{NaH}_{2} \mathrm{PO}_{4} \cdot 2 \mathrm{H}_{2} \mathrm{O}, 0.02 \mathrm{M}$ $\mathrm{Na}_{2} \mathrm{HPO}_{4} \cdot 2 \mathrm{H}_{2} \mathrm{O}, 0.15 \mathrm{M} \mathrm{NaCl}, \mathrm{pH}$ 7.2) and their concentration adjusted to $2 \times 10^{9}$ bacteria ml $^{-1}$

Fish. Rainbow trout were obtained from a local fish farm and maintained in $150 \mathrm{l}$ tanks supplied with aerated flow-through dechlorinated water. The water temperature during the experimental period was $15 \pm$ $2^{\circ} \mathrm{C}$. Rainbow trout weighing 300 to $400 \mathrm{~g}$ were used for the isolation of head kidney macrophages, while trout weighing 800 to $900 \mathrm{~g}$ were used to raise antisera against Mycobacterium.

Fish immunisation. Extracellular products (ECP) from Mycobacterium marinum and Mycobacterium sp. TB267 were prepared according to Chen et al. (1996) and mixed with Freund's incomplete adjuvant (FIA) at a ratio of $1: 1(\mathrm{v} / \mathrm{v})$. Sixteen rainbow trout were divided equally into 2 groups and placed in separate tanks. Fish in group 1 were immunised with $0.3 \mathrm{ml}$ of ECP from strain TB267, while group 2 fish were immunised with $0.3 \mathrm{ml}$ of ECP from $M$. marinum. Each fish received $150 \mathrm{\mu g}$ of protein intraperitoneally (i.p.), for both primary and secondary injections administered at Weeks 0 and 8 , respectively. The fish were bled $4 \mathrm{wk}$ after the secondary immunisation. Although this serum had not been heat inactivated, it had been stored at $-70^{\circ} \mathrm{C}$ for 12 mo and did not retain any complement activity.

Preparation of monoclonal antibody (MAb) ascites. MAbs against the ECP of mycobacteria had previously been prepared by Chen et al. (1997). MAb against the $65 \mathrm{kDa}$ protein of TB267 (cell line 4B9, IgG1), grown in mouse ascites, was used in the current study to opsonise the bacteria. Six male Balb/c mice, 6 to $8 \mathrm{wk}$ in age, were injected i.p. with $0.5 \mathrm{ml}$ pristane. After $7 \mathrm{~d}$ the mice were injected i.p. with $0.5 \mathrm{ml}$ of hybridoma suspension $\left(3 \times 10^{6}\right.$ cells in PBS). Ascites developed 10 to $14 \mathrm{~d}$ later and was drained from the peritoneal cavity of the mouse with a 19 gauge needle after having first anaesthetised the animal.

Opsonisation of bacteria. Bacteria $\left(2 \times 10^{9}\right.$ bacteria $\mathrm{ml}^{-1}$ ) were pre-treated with different preparations of opsonins: either $1 \mathrm{ml}$ of PBS; $0.5 \mathrm{ml}$ of PBS containing $20 \%(\mathrm{v} / \mathrm{v})$ fresh serum from rainbow trout (FS); $1 \mathrm{ml}$ $20 \%(\mathrm{v} / \mathrm{v})$ fresh serum from rainbow trout which had been heat inactivated at $48^{\circ} \mathrm{C}$ for $30 \mathrm{~min}$ (HIS) and diluted in PBS; rainbow trout antisera against the ECP of TB267 or Mycobacterium marinum diluted 5 times with PBS (Ab); or ascites containing MAb against the $65 \mathrm{kDa}$ protein of TB267 (cell line 4B9) diluted 5 times with PBS. The bacteria were incubated with the different preparations for $1 \mathrm{~h}$ at $18^{\circ} \mathrm{C}$, after which they were washed twice with PBS and resuspended in $0.5 \mathrm{ml}$ PBS.

Isolation of macrophages. Macrophage cell suspensions were prepared from head kidney tissue according to Secombes (1990) by teasing the tissue through a $100 \mu \mathrm{m}$ nylon gauge into Leibovitz-15 medium (L-15) (Sigma, UK) containing 10 i.u. heparin $\mathrm{ml}^{-1}, 1 \%$ penicillin/streptomycin (P/S) and $2 \%$ foetal calf serum (FCS). The resulting cell suspension was layered onto a $34 / 51 \%(\mathrm{v} / \mathrm{v})$ Percoll gradient and centrifuged at $400 \times g$ for $30 \mathrm{~min}$ at $4^{\circ} \mathrm{C}$. The leukocytes at the interface were collected and washed with L-15 medium by centrifuging at $400 \times g$ for $10 \mathrm{~min}$. In order to obtain sufficient macrophages to perform all the phagocytic assays at the same time, cells from 16 fish were pooled. The cell pellet was resuspended in L-15 to a cell concentration of $1.0 \times 10^{7}$ cells $\mathrm{ml}^{-1}$ and used immediately.

Phagocytic assay. One $\mathrm{ml}$ aliquots of the macrophage suspension were placed in polystyrene culture tubes and $100 \mu \mathrm{l}$ of opsonised bacteria $\left(2 \times 10^{9}\right.$ cells $\mathrm{ml}^{-1}$ ) were added to the tubes and gently mixed. The tubes were incubated for $0.5,1,2,4$, or $6 \mathrm{~h}$ at $18^{\circ} \mathrm{C}$ with intermittent shaking. The macrophages were then rinsed with cacodylate solution by centrifuging the tubes at $400 \times g$ for $7 \mathrm{~min}$ at $4^{\circ} \mathrm{C}$. The resulting pellets were fixed with $2 \%(\mathrm{v} / \mathrm{v})$ glutaraldehyde diluted in cacodylate buffer $(0.1 \mathrm{M}, \mathrm{pH}$ 7.2) for $1 \mathrm{~h}$ and the tubes were again centrifuged and post-fixed with $1 \%$ osmium tetroxide for $1 \mathrm{~h}$. The pellets were dehydrated with acetone before embedding in Epon 812 (Agar Scientific Ltd, UK). Thin sections of the pellets were prepared and stained with uranyl acetate and lead citrate, and observed with a Philips EM301 electron microscope. Bacteria were considered damaged if they had an abnormal appearance, such as breaks in their cell wall, disorganisation of cytoplasmic membrane or 
disorganisation of the nuclear region. Bacteria considered to be undamaged were classified intact. One hundred macrophages were counted from each preparation and 3 replicates for each fish were examined for each preparation. The results are presented as mean $\pm \mathrm{SE}$ for 3 fish. One-way ANOVA and Student's $t$-test were used to calculate $p$. A level of $p<0.05$ was considered statistically significant.

Ferritin labelling. Labelling of lysosomes with ferritin was carried out according to Armstrong \& Hart (1971). Macrophage monolayers were prepared by adhering the cells to coverslips for $24 \mathrm{~h}$. The coverslips were washed 3 times with PBS, then covered with $0.5 \mathrm{ml} \mathrm{L}-15$ medium containing 5\% FCS and ferritin (Sigma) at a final concentration of $20 \mathrm{mg} \mathrm{ml}^{-1}$ and incubated for $3 \mathrm{~h}$ at $16^{\circ} \mathrm{C}$. The cover-

slips were washed again 3 times with L-15 medium to remove free ferritin from the cell layer. L-15 medium containing $5 \%$ FCS was added to the coverslips, which were incubated for a further $3 \mathrm{~h}$ to allow complete ingestion of the ferritin. Macrophages were allowed to phagocytosis the mycobacteria as described above for 2 and $4 \mathrm{~h}$ at $18^{\circ} \mathrm{C}$. Cells were harvested using a Pasteur pipette to wash the slides with cold L-15. The resulting cell suspensions were centrifuged at $400 \times g$ for $7 \mathrm{~min}$ at $4^{\circ} \mathrm{C}$, the pellets fixed as above and examined by electron microscopy (EM). The technique of labelling macrophage lysosomes with electro-dense ferritin allowed lysosomal fusion to be examined by EM because of the presence of the dark electro-dense labelling of the phagolysosome.

Examination of infected fish tissue. Tissue sections were sampled from Siamese fighting fish Betta splendens (Regan) infected with mycobacteriosis and the ultrastructure of macrophages examined in situ by EM. Tissues were cut into small pieces $\left(1 \mathrm{~mm}^{3}\right)$ and immersed in Karnovsky fixative overnight at $4^{\circ} \mathrm{C}$, then post-fixed at $4^{\circ} \mathrm{C}$ for $1 \mathrm{~h}$ in $1 \%$ osmium tetroxide in the same buffer, dehydrated in acetone and embedded in araldite. Semi-thin sections were stained with $1 \%$ aqueous solution of toludine blue in borax. Ultra-thin sections were transferred to copper grids, stained with uranyl acetate and lead citrate, and examined by EM.

\section{RESULTS}

Ultra-thin sections of macrophages incubated with pre-opsonised bacteria were examined by EM. Macro- phages were characterised by their abundant cytoplasm, eccentric nucleoli, large golgi region, numerous mitochondria and moderately abundant rough endoplasmic reticulum. The morphology of the macrophages varied in the number of indentations each cell possessed. Some were monopodic, while others were multipodic with appendices gathering together to form a foot structure.

After $0.5 \mathrm{~h}$ incubation, the majority of engulfed bacteria (both TB267 and Mycobacterium marinum) as well as extracellular bacteria appeared normal. Some macrophages appeared capable of phagocytosing many bacteria, all of which were at different stages of ingestion. The number of engulfed bacteria was usually around 3 to 5 cells per macrophage. The percentage of macrophages which phagocytosed bacteria was significantly greater after pre-treating the bacteria with FS, Ab or MAb (46, 53.5, 41.1\% for TB267 and $43.6,41.3,36 \%$ for $M$. marinum, respectively) than bacteria pre-treated with PBS or HIS $(26.3,25.6 \%$ for TB267 and $24.3,25.7 \%$ for $M$. marinum, respectively) (Table 1).

The morphology of the macrophage sometimes changed after engulfment. Fig. 1 shows the EM analysis of a macrophage after 30 min incubation with TB267 (pre-incubated with fish anti-TB267 ECP antibody). The plasma membrane shows an indented outline, with natatory appendices gathered together as a sort of foot. Some bacteria have been engulfed by the macrophage, and immediately adjacent to the bacteria are several dense granules resembling lysosomes. The macrophage shown in Fig. 2, after 30 min incubation with Mycobacterium marinum (pre-incubated with 

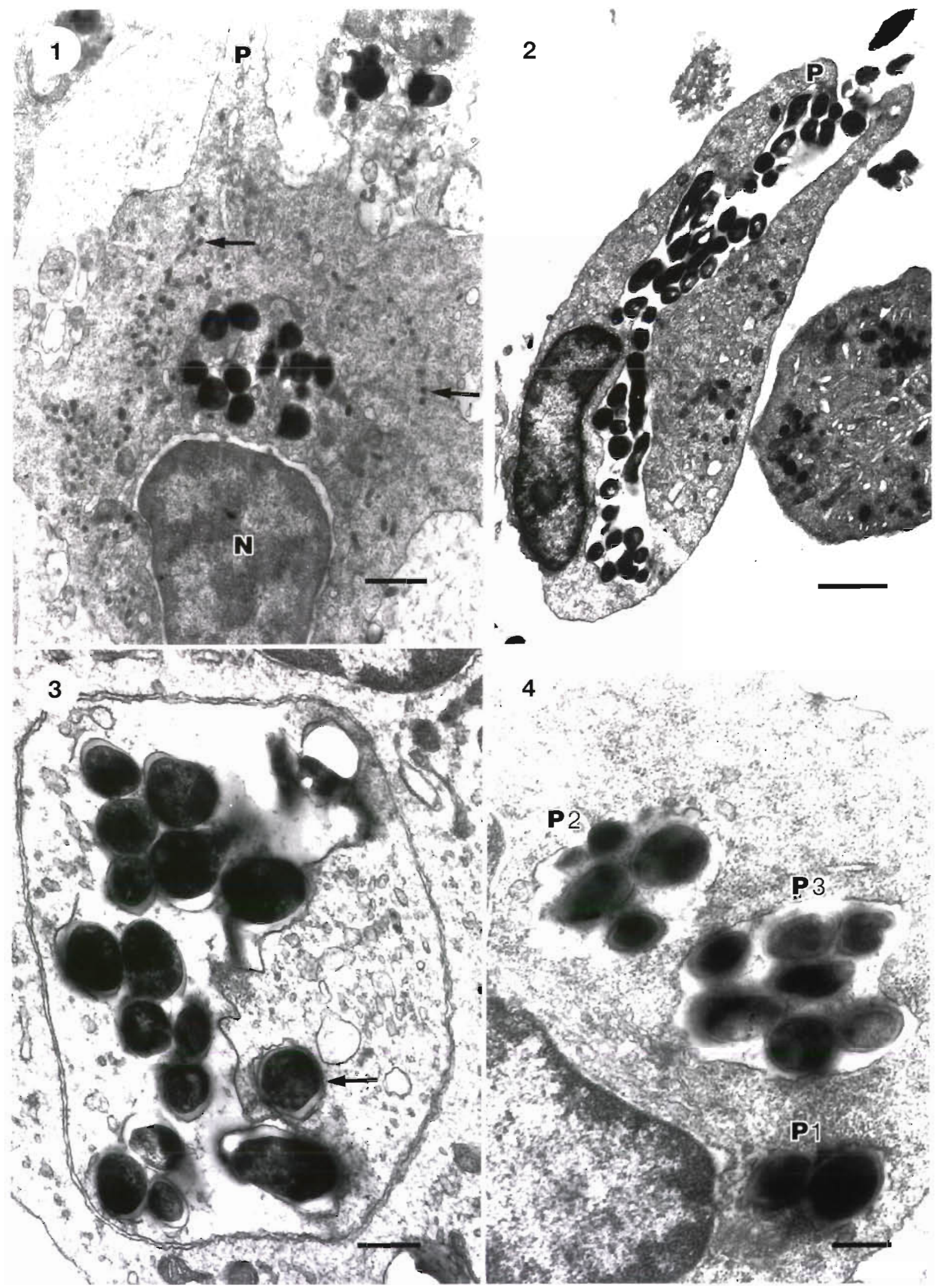
Figs. 1 to 4. Oncorhynchus mykiss macrophages. Fig. 1. EM of a macrophage after 30 min incubation with TB267 (pre-incubated with fish anti-TB267 ECP antibody). The spread and changing plasma membrane shows a much indented, multipodic outline (P), the natatory appendices being gathered as a sort of foot. One pole of cell contains the nucleus ( $N$ ), while the other pole contains many mitochondria and lysosomes (arrows). Some bacteria have been engulfed by the macrophage. Scale bar $=1.0 \mu \mathrm{m}$ Fig. 2. EM of a macrophage after 30 min incubation with Myctobacterium marinum (pre-incubated with PBS). Bacteria are being engulfed by 2 pseudopodia (P). Scale bar $=1.7 \mu \mathrm{m}$. Fig. 3. EM of a macrophage after $4 \mathrm{~h}$ incubation with TB267 (pre-1ncubated with fish anti-TB267 ECP antibody). The cell has phagocytosed many bacteria. One bacterium in the phagosome is surrounded by a 2 -layer phagosomal wall (arrow). Scale bar $=0.55 \mu \mathrm{m}$. Fig. 4 . EM of a macrophage after $4 \mathrm{~h}$ incubation with $M$. marinum (pre-incubated with heat-inactivated fish serum). The cell has phagocytosed many bacteria. A phagosome (P1) containing 2 bacteria has fused with a lysosome. A phagosome (P2) containing 5 bacteria and a 7 bacteria phagosome (P3) are visible at different stages of ingestion. Scale bar $=0.45 \mu \mathrm{m}$

PBS), has an elongated shape, with bacteria being engulfed by 2 pseudopodia. Thus, changes to the shape of the nucleus appear to be dependent on the morphology of the plasma membrane. Macrophages incubated for $0.5 \mathrm{~h}$ with TB267 or $M$. marinum, pretreated with MAb, generally all appeared elongated in shape with one end of the cell containing many mitochondria.

Distinct stages of phagosome formation were evident during the early stages of the ingestion of Mycobacterium marinum, with the bacteria eventually becoming completely enclosed within membranebound vacuoles or phagosomes, and bacteria which appeared to adhere tightly to the surface of macrophages showed more advanced stages of phagosome formation. Phagosomes varied in size and contained intact as well as a few damaged bacteria. The phagosome usually contained 1 or 2 bacteria per phagosome (Table 2), but larger phagosomes containing several bacilli were also evident. There were no signs of bacteria in the cytoplasm after $0.5 \mathrm{~h}$ incubation.

After $1 \mathrm{~h}$ incubation with bacteria, the macrophages were found to contain between 5 and 10 bacteria per cell. A few of the macrophages contained between 50 to 60 bacteria, and the phagosomes varied greatly in size between the macrophages. There was no significant increase in the percentage of phagocytic cells within treatments (Table 1) or the number of phagosomes after 1 h incubation compared with 0.5 h (Table 2).

Macrophages cultured for $2 \mathrm{~h}$ with the Mycobacterium marinum showed more engulfed bacteria per cell (10 to 20) than when cultured for 0.5 or $1 \mathrm{~h}$. Some of the mycobacteria-laden macrophages had extensive vacuolation and contained few organelles. Numerous granules occupied the peri-bacterial space, while other bacteria had lost their transparent capsule and had broken cell walls and membranes. However, most bacteria pre-opsonised with HIS and PBS remained intact. Bacterial damage was greater in the $\mathrm{Ab}$ and $\mathrm{MAb}$-opsonised groups of bacteria at this time than occurred with other 3 groups of bacteria, for both strains of mycobacteria (Table 3). Moreover, macrophages incubated with bacteria opsonised with $\mathrm{Ab}$ or $\mathrm{MAb}$ possessed a large number of phagosomes containing damaged bacteria (52 and $66 \%$ for TB267 and 49 and $63 \%$ for $M$. marinum, respectively) (Table 3 ). Few bacteria were damaged when they were pre-treated with PBS, FS or HIS $(8,9$ and $4 \%$ of TB267 were damaged and 36,19 and $33 \%$ of $M$. marinum were damaged) (Table 3 ).

After 4 h incubation, generally between 20 to 25 bacteria were seen in each phagocytic macrophages. although some had engulfed more than 100 bacteria. The number of phagosomes present varied from cell to cell. They each contained approximately 3 bacteria, although larger phagosomes containing more than this were observed. In some instances the engulfed bacte-

Table 2. Number of phagosomes produced per rainbow trout macrophage after different incubation times. 50 phagocytic cells counted (data from 3 samples, mean \pm SE). PBS: phosphate buffered saline; FS: rainbow trout fresh serum; HIS: rainbow trout heat-inactivated serum; $\mathrm{Ab}$ : rainbow trout anti-TB267 or Mycobacterium marinum (NCIMB 1298) ECP antibody; 65K MAb: mouse antiTB267 ECP-65 kDa protein monoclonal antibody ascites; Mm: M. marinum NCIMB 1298; 267: Mycobacterium sp. (TB267) isolated from snakehead fish Channa striata (Bloch)

\begin{tabular}{|c|c|c|c|c|c|}
\hline \multirow[t]{2}{*}{ Strains } & \multicolumn{5}{|c|}{ Incubation time (h) } \\
\hline & 0.5 & 1 & 2 & 4 & 6 \\
\hline $267+\mathrm{PBS}$ & $1.36 \pm 0.6$ & $1.89 \pm 1.0$ & $2.63 \pm 2.4$ & $2.54 \pm 1.3$ & $2.96 \pm 2.1$ \\
\hline $267+\mathrm{FS}$ & $1.96 \pm 1.1$ & $2.56 \pm 1.1$ & $2.55 \pm 1.6$ & $4.00 \pm 2.4$ & $3.90 \pm 1.2$ \\
\hline $267+\mathrm{HIS}$ & $1.70 \pm 0.9$ & $2.03 \pm 1.1$ & $3.01 \pm 2.4$ & $2.30 \pm 1.5$ & $2.5 \pm 0.6$ \\
\hline $267+267 \mathrm{Ab}$ & $1.85 \pm 0.8$ & $3.35 \pm 1.9$ & $3.17 \pm 1.9$ & $2.86 \pm 2.0$ & $3.17 \pm 1.2$ \\
\hline $267+65 \mathrm{~K} \mathrm{MAb}$ & $2.38 \pm 1.2$ & $2.87 \pm 2.0$ & $3.97 \pm 2.6$ & $3.61 \pm 1.4$ & $3.71 \pm 0.6$ \\
\hline $\mathrm{Mm}+\mathrm{PBS}$ & $1.37 \pm 0.8$ & $1.46 \pm 0.7$ & $3.37 \pm 2.6$ & $2.50 \pm 1.5$ & $2.80 \pm 1.1$ \\
\hline $\mathrm{Mm}+\mathrm{FS}$ & $1.92 \pm 1.1$ & $2.92 \pm 1.8$ & $4.12 \pm 1.5$ & $4.00 \pm 1.5$ & $4.89 \pm 2.4$ \\
\hline $\mathrm{Mm}+\mathrm{HIS}$ & $1.57 \pm 0.7$ & $2.25 \pm 1.3$ & $2.28 \pm 1.2$ & $2.27 \pm 1.4$ & $2.60 \pm 1.8$ \\
\hline $\mathrm{Mm}+\mathrm{Mm} \mathrm{Ab}$ & $2.69 \pm 1.3$ & $3.04 \pm 1.4$ & $3.59 \pm 1.8$ & $3.86 \pm 2.0$ & $3.30 \pm 1.0$ \\
\hline $\mathrm{Mm}+65 \mathrm{~K} \mathrm{MAb}$ & $2.50 \pm 1.5$ & $3.06 \pm 1.6$ & $3.58 \pm 1.6$ & $3.83 \pm 1.5$ & $3.20 \pm 1.3$ \\
\hline
\end{tabular}




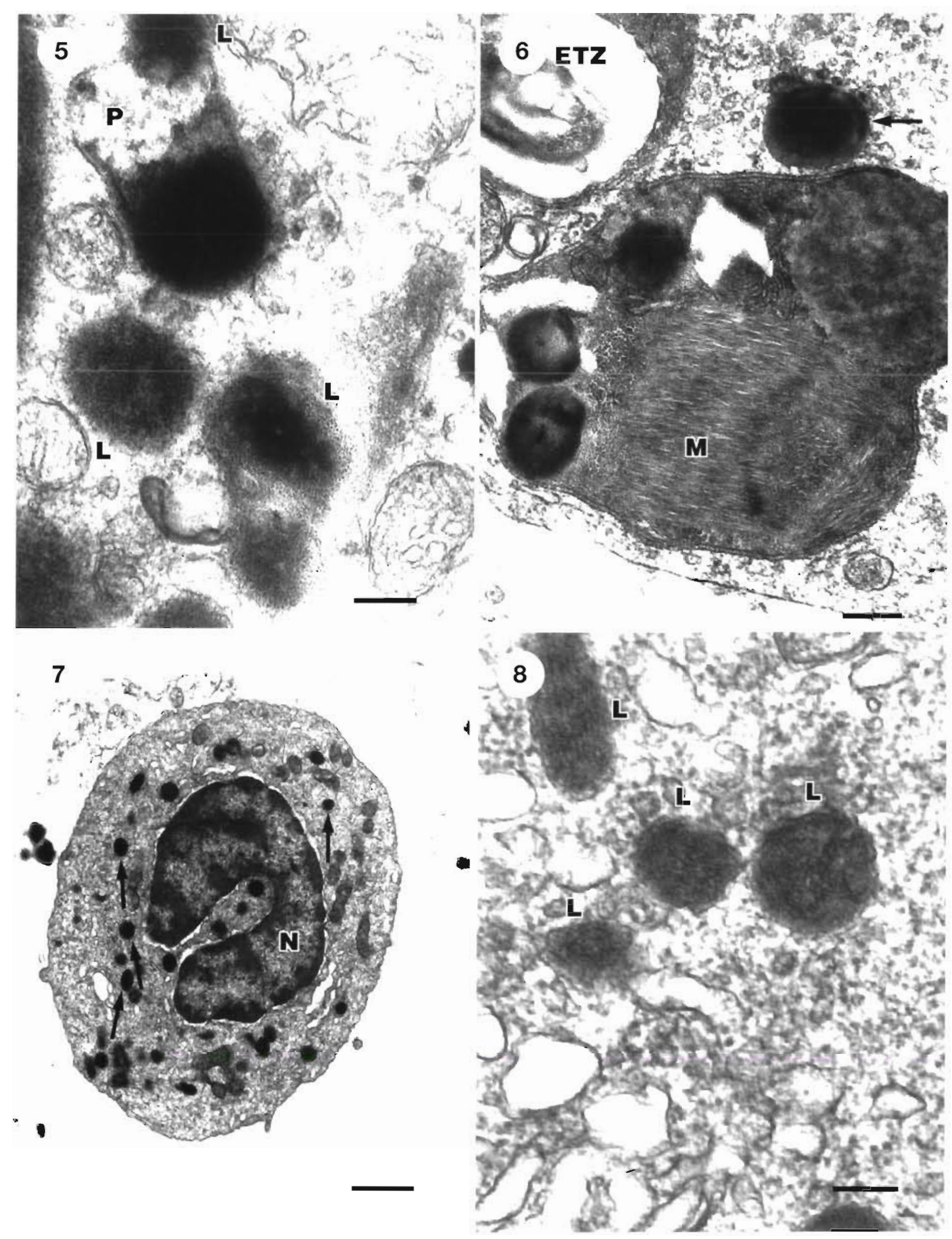


Figs 5 to 8. Oncorhynchus mykiss macrophages. Fig. 5. EM of a macrophage after $4 \mathrm{~h}$ incubation with TB267 (pre-incubated with PBS). The phagosome (P) has fused with the lysosome (L). The bacterium is in an advanced stage of digestion within phagocytic vacuoles. Scale bar $=0.28 \mu \mathrm{m}$. Fig. 6. EM of a macrophage after $6 \mathrm{~h}$ incubation with Mycobacterium marinum (pre-incubated fish fresh serum). Marked lysosome phagosome fusion has occurred. Increased degrees of $M$. marinum damage, with myelin (M) figure development. Another phagosome has an irregular electro-transparent zone (ETZ). A bactenum (arrow) is escaping from the phagosome into the cytoplasm of the macrophage. Scale bar $=0.35 \mu \mathrm{m}$. Fig. 7 . EM of a macrophage from a $1 \mathrm{~d} c u l t u r e$ in $\mathrm{L}-15$ The cell had been pre-incubated with ferrtin. Dense granules, or secondary lysosomes (arrows) are abundant, varying both in size and in content density. Scale bar $=0.14 \mu \mathrm{m}$. Fig. 8. Four dense granules, lysosome (L) at higher magnification, showing the limiting unit membrane. Scale bar $=0.17 \mu \mathrm{m}$

ria appeared to be surrounded by a phagosome which possessed a double wall (Fig. 3), while in other macrophages, the phagosomes had fused with lysosomes (Fig. 4)

Macrophages incubated for more than $6 \mathrm{~h}$ with bacteria contained numerous intra-phagosomal bacteria. Partially digested bacteria were observed in lysosomes as granule contents, and bacteria were also observed being digested in the phagolysosome (Fig. 5). There

Table 3. Percentage of intact and damaged bacteria in rainbow trout macrophage after ingestion of Mycobacterium spp. assessed by electron microscopy. PBS: phosphate buffered saline; FS: rainbow trout fresh serum; HIS: rainbow trout heat-inactivated serum; Ab: rainbow trout anti-TB267 or $M$. marinum (NCIMB 1298) ECP antibody; 65K MAb: mouse anti-TB267 ECP-65 kDa protein monoclonal antibody; Mm: $M$. marinum NCIMB; 267: Mycobacterium sp. (TB267) isolated from snakehead fish Channa striata (Bloch)

\begin{tabular}{|c|c|c|c|c|c|}
\hline \multirow{2}{*}{$\begin{array}{l}\text { Incubation } \\
\text { time (h) }\end{array}$} & \multirow[t]{2}{*}{ Strains } & \multirow{2}{*}{$\begin{array}{c}\text { Bacilli } \\
\text { encountered }\end{array}$} & \multicolumn{3}{|c|}{ Appearance of bacteria $(\%)$} \\
\hline & & & Intact & Damaged & Doubtful \\
\hline \multirow[t]{10}{*}{2} & $267+\mathrm{PBS}$ & 120 & 91 & 8 & 1 \\
\hline & $267+\mathrm{FS}$ & 208 & 90 & 9 & 1 \\
\hline & $267+$ HIS & 123 & 93 & 4 & 3 \\
\hline & $267+267 \mathrm{Ab}$ & 178 & 41 & 52 & 7 \\
\hline & $267+65 \mathrm{~K} \mathrm{MAb}$ & 101 & 28 & 66 & 6 \\
\hline & $\mathrm{Mm}+\mathrm{PBS}$ & 59 & 64 & 36 & 0 \\
\hline & $M m+F S$ & 164 & 77 & 19 & 4 \\
\hline & $\mathrm{Mm}+\mathrm{HIS}$ & 107 & 61 & 33 & 6 \\
\hline & $\mathrm{Mm}+\mathrm{Mm} \mathrm{Ab}$ & 216 & 47 & 49 & 8 \\
\hline & $\mathrm{Mm}+65 \mathrm{~K} \mathrm{MAb}$ & 132 & 32 & 63 & 7 \\
\hline \multirow[t]{10}{*}{4} & $267+\mathrm{PBS}$ & 173 & 88 & 5 & 7 \\
\hline & $267+\mathrm{FS}$ & 223 & 22 & 76 & 2 \\
\hline & $267+\mathrm{HIS}$ & 228 & 76 & 11 & 13 \\
\hline & $267+267 \mathrm{Ab}$ & 228 & 34 & 63 & 3 \\
\hline & $267+65 \mathrm{~K} \mathrm{MAb}$ & 228 & 15 & 76 & 9 \\
\hline & $\mathrm{Mm}+\mathrm{PBS}$ & 226 & 63 & 30 & 7 \\
\hline & $\mathrm{Mm}+\mathrm{FS}$ & 167 & 40 & 54 & 6 \\
\hline & $\mathrm{Mm}+\mathrm{HIS}$ & 160 & 60 & 37 & 3 \\
\hline & $M m+1298 \mathrm{Ab}$ & 100 & 39 & 59 & 2 \\
\hline & $\mathrm{Mm}+65 \mathrm{~K} \mathrm{MAb}$ & 70 & 24 & 67 & 9 \\
\hline \multirow[t]{10}{*}{6} & $267+P B S$ & 203 & 67 & 23 & 10 \\
\hline & $267+F S$ & 60 & 28 & 65 & 7 \\
\hline & $267+$ HIS & 123 & 79 & 18 & 3 \\
\hline & $267+267 \mathrm{Ab}$ & 127 & 15 & 82 & 3 \\
\hline & $267+65 \mathrm{~K} \mathrm{MAb}$ & 100 & 17 & 80 & 3 \\
\hline & $\mathrm{Mm}+\mathrm{PBS}$ & 125 & 50 & 39 & 11 \\
\hline & $\mathrm{Mm}+\mathrm{FS}$ & 142 & 25 & 49 & 6 \\
\hline & $\mathrm{Mm}+\mathrm{HIS}$ & 150 & 69 & 28 & 3 \\
\hline & $\mathrm{Mm}+\mathrm{Mm} \mathrm{Ab}$ & 174 & 8 & 85 & 7 \\
\hline & $\mathrm{Mm}+65 \mathrm{~K} \mathrm{MAb}$ & 182 & 20 & 78 & 2 \\
\hline
\end{tabular}

was an increase in the extent of phagosome lysosome fusion and the degree of bacteria damage with myelin figure development. In Fig. 6, one of the phagosomes had changed to a residual body-like structure (bacteria had disappeared and there was marked myelin formation). A bacterium can also be seen free in the cytoplasm. Increased Mycobacterium damage appears to occur with the myelin figure development. At 4 and $6 \mathrm{~h}$ the bacterial damage that was observed was greater in the $\mathrm{Ab}, \mathrm{FS}$ and $\mathrm{MAb}$ opsonised groups of bacteria than was observed with the PBS and HIS groups of bacteria, for both strains of mycobacteria (Table 3).

Phagosome lysosome fusion in bacteria-ingested macrophages was examined by EM using ferritin to prelabel the lysosomes. Electron-dense ferritin staining was found in lysosomes of macrophages before incubating with bacteria (Figs. $7 \& 8$ ). Ferritin-labelled macrophages displayed a lack of phagosome lysosome fusion when incubated with live TB267 (Fig. 9). In contrast, Fig. 10 illustrates phagosomes in which macrophages had engulfed formalin-killed organisms. There appeared to be no inhibition of their fusion with lysosomes, and some of the bacteria they contained had been digested by lysozyme.

Tissues from Siamese fighting fish infected with Mycobacterium spp. were also studied by EM to examine the formation of phagosomes in response to the bacterium in situ. Most bacteria were found intact in the phagosomes of macrophages from spleen (Fig. 11). Some phagosomes appeared to be surrounded by lysosomes (Figs. 12 \& 13), while others appeared to have fused with the lysosomes and contained degenerated or lysed bacteria (Fig. 14). 


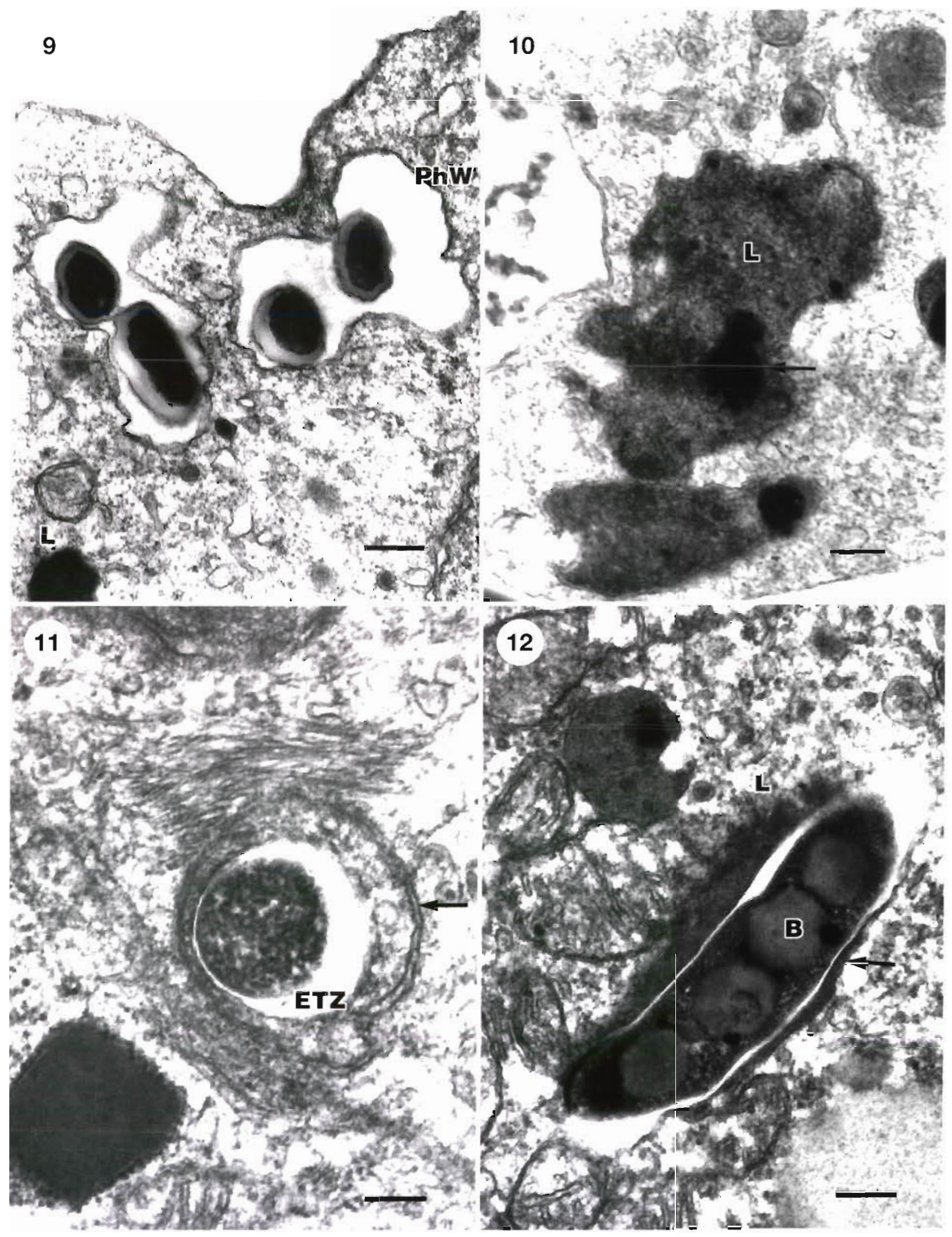


Figs. $9 \&$ 10. Oncorhynchus mykiss macrophages. Fig. 9. EM of a macrophage after $2 \mathrm{~h}$ incubation with Mycobacterium TB267. The macrophage received a standard ferritin pulse before infection. The organism is bounded by a typical plasma membrane and a morphological cell wall. An irregular electro-transparent zone separates each organism from the phagosome wall (PhW) Lysosomes (L) are observed around the phagosomes but have not fused with th. Scale bar $=0.35 \mu \mathrm{m}$. Fig. 10. EM of a macrophage after $4 \mathrm{~h}$ incubation with formalin-killed Mycobacterium TB267. The macrophage received a standard ferritin pulse before infection. The lysosomes (L) have fused with phagosome. Bacterla (arrow) in the phagolysosome have been damaged by lysozyme. Some of the bacteria have been digested. Scale bar $=0.36 \mu \mathrm{m}$

Figs. 11 \& 12. Betta splendens macrophages. Fig. 11. EM of a macrophage from the spleen of Siamese fighting fish. The lysosome has fused with the phagosome. The bacteria are still intact within the phagosome. ETZ: electro-transparent zone. Phagosomal wall (arrow). Scale bar $=0.28 \mu \mathrm{m}$. Fig. 12. EM of a macrophage from the spleen of Siamese fighting fish. The lysosome (L) has fused with the phagosome. The bacterium (B) is still intact withn the phagosome. Arrow: phagosomal wall. Scale bar $=0.28 \mu \mathrm{m}$

\section{DISCUSSION}

Phagocytosis is a complex process involving attachment of a particle to the cell surface, followed by ingestion, which involves the formation of micro-projections of plasma membrane around the particle and membrane fusion. In the present study, macrophages underwent morphological changes after phagocytosis, consisting of elongation and segregation of the nucleus and organelles to one end of the cell. The level of phagocytosis of bacteria which occurred after $0.5 \mathrm{~h}$ incubation was low ( 3 to 5 bacteria per macrophages), but bacteria opsonised with FS, Ab and MAb had a higher percentage of engulfment than bacteria coated with PBS or HIS. It has been reported that macrophage monolayers from normal mice infected in vitro exhibited little ability to kill Mycobacterium microti. However, if the bacteria were first treated with supernatants from immunologically activated spleen cells, they could kill more than $90 \%$ of the phagocytosed

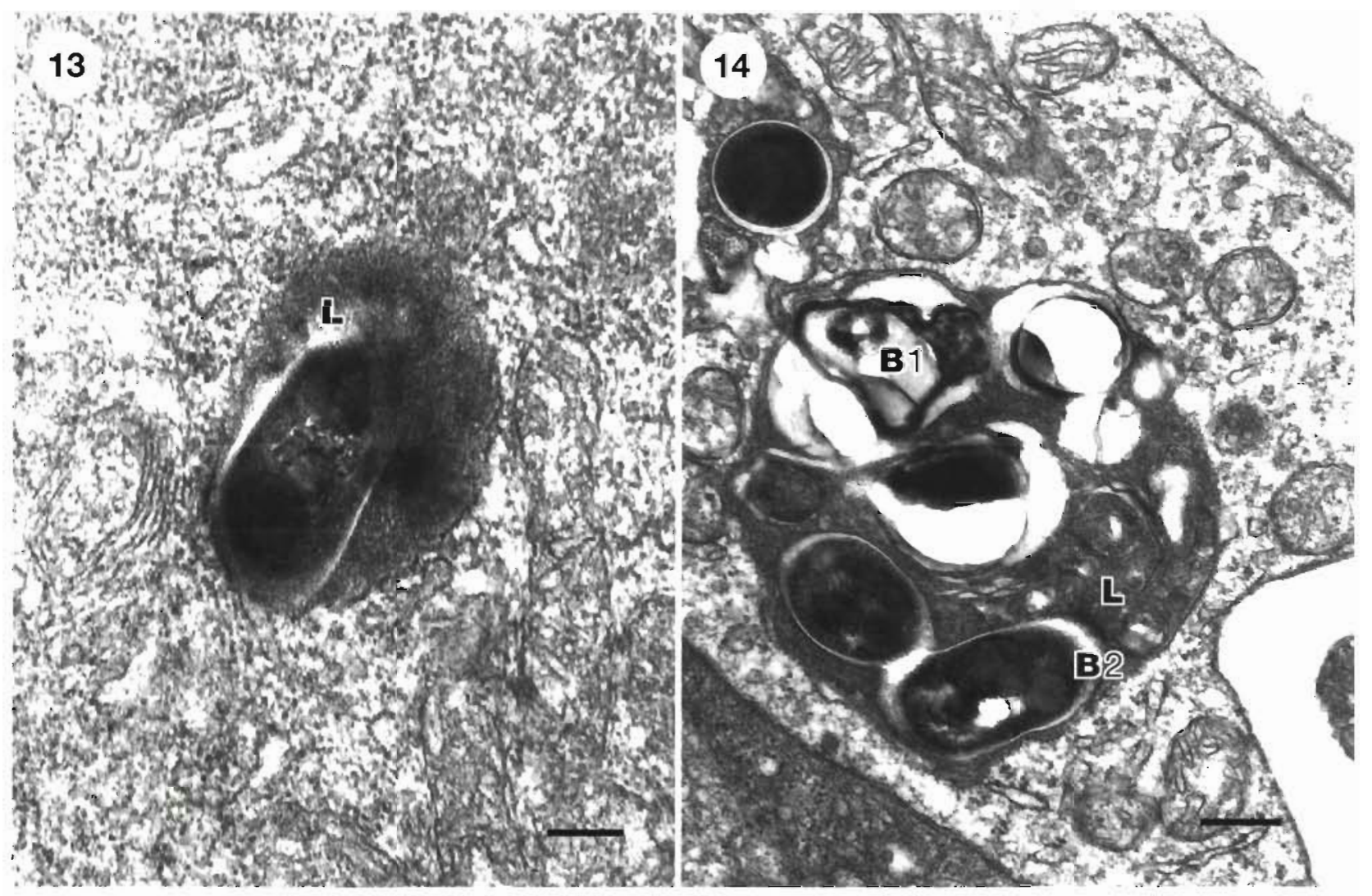

Figs. 13 \& 14. Betta splendens. Fig. 13. EM of a macrophage from the spleen of Siamese fighting fish. A lysosome (L) has fused with the phagosome and the bacterium has lost its transparent zone. Scale bar $=0.28 \mu \mathrm{m}$. Fig. 14. EM of a phagolysosome observed in the macrophage from Siamese fighting fish spleen. Lysosomes (L) have fused with phagosomes. Some bacteria (B1) have lost their transparent zone. Other bacteria (B2) are still intact. Scale bar $=0.45 \mu \mathrm{m}$ 
bacilli within 24 h (Lowrie 1983). Opsonization of foreign particles by serum factors, such as specific antibodies or complement, is often necessary for optimal ingestion. For instance, Griffin (1983) showed that the presence of specific antibody greatly enhanced the phagocytosis of Yersinia ruckeri by rainbow trout leukocytes; however, it did not affect intracellular killing. Conversely, the phagocytic activity of salmonid peritoneal exudate cells against Aeromonas salmonicida was only slightly enhanced by specific antibody. The addition of both specific antibody and complement together, however, greatly increased phagocytosis (Sakai 1984, Honda et al. 1985, 1986, Olivier et al. 1986, Blazer 1989). Bandin et al. (1995) showed that opsonisation of Renibacterium salmoninarum with specific antisera and complement significantly enhanced the survival and growth of the bacteria following phagocytosis by normal rainbow trout macrophages. In the present study, there was a significant increase in the level of phagocytosis in the FS, Ab and MAb groups as well as enhanced intracellular killing of bacteria after 2, 4 and $6 \mathrm{~h}$ incubation. Complement proved an effective opsonin in this study, since the FS group gave significantly higher levels of phagocytosis than fish serum after heating (HIS). Although mouse MAb increased the level of phagocytosis in this study, verification is necessary to establish whether rainbow trout macrophages $F_{C}$ receptors recognise mouse $\mathrm{MAb}$ (IgG1). The enhanced phagocytosis which was observed with MAb-opsonised mycobacteria may have been due simply to macrophage stimulation by the presence of immune complexes.

Macrophages are important cells in the disease resistance of the fish. Although their activity is nonspecific in nature, they play a significant role as accessory cells in the initiation of the specific immune response. They do this by recognising and phagocytosing invading particles, killing the microorganisms intracellularly, degrading them, then presenting the processed material to cells delivering a specific response (Secombes 1996). The killing mechanisms of fish macrophages are still being elucidated, although it is clear that phagocytosis and the production of oxygen free radicals via the respiratory burst are important events in bactericidal pathways (Sharp \& Secombes 1992, 1993). They also secrete soluble mediators important in inflammatory events, such as cytokines and eicosanoids (Secombes 1996). Many factors are known to effect the phagocytic activity of fish macrophages and when phagocyte mobility or killing mechanisms are affected the disease susceptibility of the fish increases (Anderson 1992). Some bacteria are able to evade the responses of the macrophage and divide and survive within these cells. This is evident with a number of fish diseases, such as bacterial kidney disease (Young \& Chapman 1978), furunculosis (Garduno et al. 1993), Edwardsiella ictaluri (Blazer et al. 1985) and with Piscirickettsia salmonis or rickettsia-like organisms (Fryer et al. 1990, Chen et al. 1994). It has been established that mycobacteria can maintain their viability and function as intracellular bacteria in mammalian macrophages (Armstrong \& Hart 1971, Davis-Scibienski \& Beaman 1980). Reports on Trypanosoma cruzi and Mycobacterium leprae suggest that these organisms are able to maintain their viability by escaping into the macrophage cytoplasm (Evans \& Levy 1972, Nogueira \& Cohn 1976). Another possible mechanism for bacterial survival was established from studies in which $M$. tuberculosis was shown to inhibit the fusion of the lysosomes with the phagosomes (Hart et al. 1987)

Different types of phagosomes were observed within the macrophages examined in this study. In the first type, one or more bacteria were present within intracellular vacuoles, but no lysosomes were present. Within the second type of vacuole, phagosomes were surrounded by lysosomes but no fusion occurred, and in the third type, phagosomes had fused with the lysosomes, but bacteria remained intact. In the fourth vacuole type, phagosomes had fused with the lysosome, and bacteria appeared damaged within the phagolysosome. Examination of a fifth type of vacuole showed phagosomes that had fused with the lysosomes and in which damaged bacteria were surrounded by myelin. Observation of the ultrastructure of phagosome lysosome fusion utilizing ferritin labelling indicated that after a $4 \mathrm{~h}$ incubation almost all phagosomes containing formalin-killed TB267 were heavily labelled, indicating a high incidence of fusion. In contrast, only $24 \%$ of phagosomes fused with lysosomes when live Mycobacterium TB267 were used. Formalin-killed Mycobacterium TB267 appeared to have lost its ability to secrete products which inhibit phagosome lysosome fusion and thus the ability to protect itself. Quantitative EM evaluation of lysosomal fusion and the morphology of Nocardia asteroides infected macrophages showed that most of the organisms of less-virulent strains were damaged after phagocytosis, and phagolysosomal fusion had occurred. In contrast, with virulent strains of $N$. asteroides neither damaged bacteria nor phagosomes were evident. It was found that the most virulent strain of $N$. asteroides, with the highest viability, was also the strain that experienced the least damage after phagocytosis (Davis-Scibienski \& Beaman 1980). Brown \& Draper (1970) showed that the electro-transparent zone (ETZ), now identified as a mycoside capsule, appeared to be a space separating intracellular $M$. lepraemurinum from lysosomal enzymes of the host macrophage. It is possible that the material in the ETZ offers some protection to the bacteria (Draper \& Rees 
1970, 1973). On the other hand, virulent tubercle bacilli, which also survive and multiply in the macrophages, seem to do so mostly in phagosomes that have not fused with the lysosomes, thus escaping direct exposure to the lysozyme.

In the present study, bacteria treated with PBS or HIS showed damage after $2 \mathrm{~h}$, suggesting that the 2 strains used were of low virulence. Strain TB267 has been subcultured in our laboratory for more than $4 \mathrm{yr}$ and, therefore, may have lost its virulence. Examination of tissue section of fish naturally infected with mycobacteriosis showed most of the mycobacteria to be within phagosomes in the macrophages. There were indications of inhibition of phagosome lysosome fusion and few mycobacteria appeared damaged. In some cases where phagolysosome fusion had occurred both damaged and intact bacteria were found within the same phagolysosome. Some mycobacteria may maintain their viability by escaping into macrophage cytoplasm. On the other hand, Mycobacterium marinum may secrete materials which inhibit phagosome lysosome fusion, since some mycobacteria survived in phagosomes after having fused with lysosomes.

Great effort has been directed towards understanding the mechanisms underlying the survival of bacteria within macrophages and the benefits which arise from avoiding contact with lysosomal contents. Three different, but possibly complementary mechanisms have been proposed: firstly, bacterial release of polyanionic cell wall components (Goren et al. 1976); secondly, release of ammonia and the release of cyclic AMP or stimulation of cyclic AMP synthesis (Lowrie et al. 1975, $1979,1980)$; and thirdly, the release of sulfatides from Mycobacterium tuberculosis inhibitors of phagolysosome fusion in macrophages cultured in vitro (Goren et al. 1976). Clearly, further studies are required to investigate the virulence of Mycobacterium spp. in snakehead fish and Siamese fighting fish and their interactions with fish macrophages.

Acknowledgements. The authors thank Dr Temdoung Somsiri, AARHl, Kasetsart Campus University, Bangkok, Thailand, for supplying the mycobacteria isolates and Ms M. Kobs for her assistance with the EM analyses.

\section{LITERATURE CITED}

Anderson DP (1992) Immunostimulants, adjuvants and vaccine carniers in fish applications to aquaculture. Annu Rev Fish Dis 2:281-308

Armstrong JA, Hart PD, D'Arcy (1971) Response of cultured macrophages to Mycobacterium tuberculosis, with observation on fusion of lysosome with phagosomes. J Exp Med $134: 713-740$

Bandin I, Rivas C, Santos Y, Secombes CJ, Barja JL, Ellis AE (1995) Effect of serum factors on the survival of Renibac- terium salmoninarum within rainbow trout macrophage. Dis Aquat Org 23(3):221-227

Blazer VS, Ankley GT, Finco-Kent D (1989) Dietary influences on disease resistance factors in channel catfish. Dev Comp Immunol 13:43-48

Blazer VS, Shotts B, Waltaman WD (1985) Pathology associated with Edwardsiella ictaluri in catfish (Ictalurus punctatus) and danio (Danio devario). J Fish Biol 26:167-176

Brown CA, Draper P (1970) An electron-microscope study of rat fibroblasts infected with Mycobacterium lepaemurium. J Pathol 102:21-26

Chen SC. Adams A, Thompson KD, Richards RH (1997) Development of monoclonal antibodies to the extracellular products of Mycobacterium spp. isolated from snakehead fish Channa striatus, and the reference strain Mycobacterium chelonae. J Aquat Anim Health 9:86-98

Chen SC, Tung MC, Chen SP, Tsai JF, Wang PC, Chen RS, Lin SC, Adams A (1994) Systematic granuloma caused by a rickettsia-like organism in Nile tilapia, Oreochromis nilotica (L.), from southern Taiwan. J Fish Dis 17:591-599

Chen SC, Yoshida T, Adams A, Thompson KD, Richards RH (1996) Immune response of rainbow trout Oncorhynchus mykiss, to extracellular products of Mycobacterium spp. $\mathrm{J}$ Aquat Anim Health 8:216-222

Chinabut S, Limsuran C, Chanratchakool P (1990) Mycobacterıosis in the snakehead, Channa striatus (Fowler). J Fish Dis 13:531-535

Davis-Scibienski C, Beaman BL (1980) Interaction of Nocardia asteroides with rabbit alveolar macrophages: association of virulence viability, ultrastructural damage, and phagosome-lysosome fusion. Infect Immun 28:610-619

Draper P, Rees JW (1970) Electron-transparent zone of mycobacterium may be a defence system. Nature 228:860

Draper P, Rees JW (1973) The nature of the electrontransparent zone that surrounds Mycobacterium lepraemurium inside host cells. J Gen Microbiol 77:79-87

Evans MJ, Levy L (1972) Ultrastrctural changes in cells of the mouse footpad infected with Mycobacterium leprac. Infect Immun 5:238-247

Fryer JL, Lannan CN, Garces LH, Larenas JJ, Smith PA (1990) Isolation of rickettsia-like organism from diseased coho salmon (Oncorhynchus kisutch) in Chile. Fish Pathol 25: $107-114$

Garduno RA, Thorton JC, Kay WW (1993) Aeromonas salmonicida grown in vivo. Infect Immun 61:3854-3862

Goren MB, Hart PD, Young MR, Armstrong JA (1976) Prevention of phagosome-lysosome fusion in cultured macrophages by sulfatides of Mycobacterium tuberculosis. Proc Natl Acad Sci 73:2510-2514

Griffin BR (1983) Opsonic effect of rainbow trout (Salmo gairdneri) antibody on phagocytosis of Yersinia ruckeri by rainbow trout leucocytes. Dev Comp Immunol 7:252-259

Hart PD, Young MR, Gordon AH, Sullivan KH (1987) Inhibition of phagosome-lysosome fusion in macrophages by certain Mycobacteria can bo explained by inhibition of lysosomal movements observed after phagocytosis. J Exp Med 166:933-946

Honda A, Kodama $H$, Moustafa M, Yamada F, Mikami $T$, Izawa H (1985) Response of rainbow trout immunized with formalin-killed Vibrio anguillarum activity of macrophages and opsonising effect of antibody. Fish Pathol 20 : $395-402$

Honda A, Kodama $H$, Moustafa M, Yamada $F$, Mikami $T$, Izawa $H$ (1986) Phagocytic activity of macrophages of rainbow trout against Vibrio anguillarum and the opsonising effect of antibody and complement. Res Vet Sci 40 : $328-332$ 
Krahenbuhl FL (1994) Role of the macrophage in resistance to leprosy. In: Bloom BR (ed) Tuberculosis: pathogenesis, protection and control. American Society for Microbiology, Washington, p 137-155

Li S, Woo PT (1995) Efficacy of a live Cryptobia salmositica vaccine, and the mechanism of protection in vaccinated rainbow trout, Oncorhynchus mykiss, against cryptobiosis. Vet Immunol Immunopathol 48:343-353

Lowrie DB (1983) How macrophages kill tubercle bacilli. J Med Microbiol 16:1-12

Lowrie DB, Aber VR, Jackett PS (1979) Phagosome-lysosome fusion and cyclic adenosine 3:5-monophosphate in macrophages infected with Mycobacterium microti, Mycobacterium bovis BCG or Mycobacterium lepraemurium. J Gen Microbiol 110:431-441

Lowrie DB, Jackett PS, Aber VR, Carrol MEW (1980) Cyclic nucleotides and phagosome-lysosome fusion in mouse peritoneal macrophage. In: van Furth $R$ (ed) Mononuclear phagocytes, functional aspects, Vol 2. Marinum Nijhoff, The Hague, p 1057-1075

Lowrie DB, Jackett PS, Ratcliffe NA (1975) Mycobacterium microti may protect itself from intracellular destruction by releasing cyclic AMP into phagosome. Nature 254: $600-602$

Nigrelli RF, Vogel H (1963) Spontaneous tuberculosis in fish and other cold-blooded vertebrates with special reference to Mycobacterium fortuitum Cruz from fish and human lesions. Zoologica 48:131-144

Noga EJ, Dykstra MJ, Wright JF (1989) Chronic inflammatory cells with epithelial cell characteristics in teleost fishes. Vet Pathol 26:429-437

Noga EJ, Wright JF, Pasarell L (1990) Some unusual features of mycobacteriosis in the cichlid fish Oreochromis mossambicus. J Comp Pathol 102:335-344

Editorial responsibility: David Bruno,

Aberdeen, Scotland, UK
Nogueira N, Cohn Z (1976) Trypanosoma cruzi: mechanism of entry and intracellular fate in mammalıan cells. J Exp Med 143:1402-1420

Olivier G, Eaton CA, Campbell N (1986) Interaction between Aeromonas salmonicida and peritoneal macrophages of brook trout (Salvelinus fontinalis). Vet Immunol Immunopathol 12:223-234

Rook GAW, Bloom BR (1994) Mechanism of pathogenesis in tuberculosis. In: Bloom BR (ed) Tuberculosis: pathogenesis, protection and control. American Society for Microbiology, Washington, p 485-501

Sakai DK (1984) Opsonization by fish antibody and complement in immune phagocytosis by peritoneal exudate cells isolated from salmonid fishes. J Fish Dis 7:29-38

Secombes CJ (1990) Isolation of salmonid macrophages and analysis of their killing activity. In: Stolen JS, Fletcher TC, Anderson DP, Robertson BS, van Muiswinkel WB (eds) Techniques in fish immunology, Vol 1. SOS Publications, Fair Haven, p 137-152

Secombes CJ (1996) The nonspecific immune system: cellular defenses. In: Iwama G, Nakanishi $T$ (eds) The fish immune system: organism, pathogen and environment. Academic Press Inc, London, p 63-103

Sharp GJE, Secombes CJ (1992) Observations on the killing of Aeromonas salmonicida by rainbow trout Oncorhynchus mykiss (Walbaum) macrophages. Dis Asian Aqua 1:379-389

Sharp GJE, Secombes CJ (1993) The role of reactive oxygen species in the killing the bacterial fish pathogen Aeromonas salmonicida by rainbow trout macrophages. Fish Shellfish Immunol 3:119-129

Young CL, Chapman GB (1978) Ultrastructural aspects of the causative agent and renal histopathology of bacterial kidney disease in brook trout (Salvelinus fontinalis). J Fish Res Bd Can 35:1234-1248

Submitted: April 9, 1997, Accepted: December 2, 1997 Proofs received from author(s): February 16, 1998 